\title{
DESIGN, FABRICATION AND PERFORMANCE EVALUATION OF A RICE DESTONING MACHINE
}

\author{
${ }^{1}$ Smart Bello, ${ }^{2}$ Samuel O. Eguoaje and ${ }^{3}$ Eriakha E. Collins \\ ${ }^{1}$ Department of Mechanical Engineering Technology, School of Engineering Technology \\ Auchi Polytechnic Auchi, Edo State \\ ${ }^{2}$ Department of Minerals and Petroleum Resources Engineering Technology, School of \\ Engineering Technology, Auchi Polytechnic Auchi, Edo State \\ ${ }^{3}$ Department of Agricultural and Bio-Environmental Engineering Technology, School of \\ Engineering Technology, Auchi Polytechnic Auchi, Edo State \\ Correspondence: ajayistan@gmail.com, +2348039714411
}

\begin{abstract}
Rice cleaning and separation has not received adequate attention in Nigeria, thus making the consumption of our locally grown rice unacceptable. These processes do not actually give the best of rice grain as some impurities and various types of contaminations of undesirable matter accompanied the rice grains. The general objective of the work is to design, fabricate and carry out the performance evaluation of a rice destoner. The destoner consists of the reciprocating and vibrating sieves. The machine was tested in terms of the rice separation efficiency, stone separation efficiency, tray loss and impurity level after separation. The result showed an average of $81.75 \%, 7.33 \%, 18.25 \%$ and $27.27 \%$ for rice separation efficiency, stone separation efficiency, tray loss and impurity after separation respectively for local rice variety under study. The developed machine has the promise of solving the problem of stone infestation usually encountered in locally produced rice.
\end{abstract}

Keywords: fabrication and performance, rice destoner

DOI: $10.7176 / \mathrm{JNSR} / 9-22-07$

Publication date: November $30^{\text {th }} 2019$

\subsection{INTRODUCTION}

Rice is a popular tropical cereal considered to be an important food item. This is because it supplies a quarter of the entire calorific intake of human race as stated by Babatunde (2004). FAO (1995) gave statistics which shows that rice is a staple food of well over $90 \%$ of the world's population. This means rice has been of very great economic importance. Therefore, availability of processing machines becomes an important essential aspect of agro-allied industries (Tukuru, 2000, Wudiri and Fatoba, 1992).

In Nigeria most of the agro-allied products are consumed or exported unprocessed, this has negative effects on the economy of our nation. The separation of grains from stone and other impurities before consumption or further processing into various products is one step that is necessary in improving agro-allied industries. This step will ensure the quality and hygiene of products, thus increasing the commercial value of the final exported or consumed products. Also, with the current increase observed in our local production of rice in Nigeria, owing largely to the present policy of government on imported items, there is need to give attention and organization to agro-allied industries and their products (Echiego, 2009).

This work therefore aims at producing Rice de-stoning machine with vibrating screens on two stages using simplified exciters. With the development of the machine for processing of rice, demand for our locally produced rice will increase with its attendant gains on the economy. Therefore introduction of an efficient and cost effective de-stoner is simply the only option left for the present day rice farmers in Nigeria. This rice de-stoner operates on the principle of size, 
shape, density and bio-mechanical properties to separate rice grain from other impurities found in the composite (Henderson and Perry, 1976).

Rice cleaning and separation has not received adequate attention in Nigeria, thus making the consumption of our locally grown rice unacceptable. Seed cleaning involve removing of foreign materials from the crop seed. In Nigeria many methods are used to clean rice viz: Traditional method that employs manual labor, less efficient, overworked the workers and consume time while the latest method in technological advanced countries involve the use of several machines that separate the admixture based on the differences in their physical as well as their aerodynamic properties. This mechanized method has recently been employed in Nigeria but the cost of buying and maintaining the machines makes it unaffordable by the local farmers. It is therefore necessary to design a low cost rice-destoning machine that could be affordable by the Nigerian farmer (Ndirika, 1993).

Rice undergoes series of processes after harvest viz: Threshing, shelling and drying. These processes do not actually give the best of rice grain as some impurities and various types of contaminations of undesirable matter accompanied the rice grains viz; common and noxious weed seeds, other crop and variety seeds, deteriorated seeds, chaffs, sand, stones and damaged seeds that should not be in the rice grains. Thus, the marketable seeds should be clean and graded before it would be good for consumption (Tukuru, 2000, Wudiri and Fatoba, 1992).

In Nigeria people don't go for the local rice because it is not properly clean/graded, which lead to the great desire for the foreign products that is properly cleaned/graded. Nigerian farmers clean rice by dropping in a windy environment for wind to blow out lighter materials. The method consume time and energy, it is inefficient and cumbersome. Commercial type cleaners/graders available in the market are of large capacity and costly. Human capacity to perform useful work is limited and the cost is relatively high (Tukuru, 2000, Wudiri and Fatoba, 1992).

The objective of the work is to design, fabricate and carry out the performance evaluation of a rice destoner.

\subsection{MATERIALS AND METHOD}

\section{Description and Working Principle of the Machine}

The destoner shown in Plate 1 consists of the following main features;

i. A feed hopper

ii. Reciprocating sieve

iii. Supporting frame

iv. Shaker mechanism

v. Transmission unit

vi. Vibrating sieve

vii. Discharge unit

The feed hopper has the shape of a frustum of a pyramid with base area $30 \mathrm{~cm} \times 30 \mathrm{~cm}$ and height of $10 \mathrm{~cm}$. The top sieve allow rice and smaller impurities to pass through while larger impurities are retain, the bottom sieve retains rice grains while impurities smaller than rice pass through to a collection tray. The sieve box is attached to a shaker mechanism that assured both horizontal and vertical movement.

The structural frame forms the mounting support of all other units with dimension of $700 \mathrm{~mm} \times 350 \mathrm{~mm} \times 850 \mathrm{~mm}$, length, breadth and height respectively.

The whole admixture (rice grains and impurities) will be feed into the hopper, it then move under gravity to the screening unit (sieve box) and falls directly on the top sieve where larger impurities are retained while rice and smaller impurities pass to the bottom sieve which retain rice and allow smaller impurities to pass through. The rice grains and impurities of equal 
size with rice are then moved to the final screening unit (air stream) where the rice grains are being blown to a collector for packaging.

\section{Design Consideration}

Some factors were considered during the course of the design which includes the positioning of the hopper at the top of the reciprocating sieve to move along with it, selection of gear reduction electric motor to aid the movement of the sieves, determining the diameter of the reciprocating sieve to retain bigger stones and impurities, determining the diameter of the vibrating sieve to retain rice and allow the impurities smaller than rice to pass through, cost of fabrication, maintenance, efficiency and other characteristics were also considered.

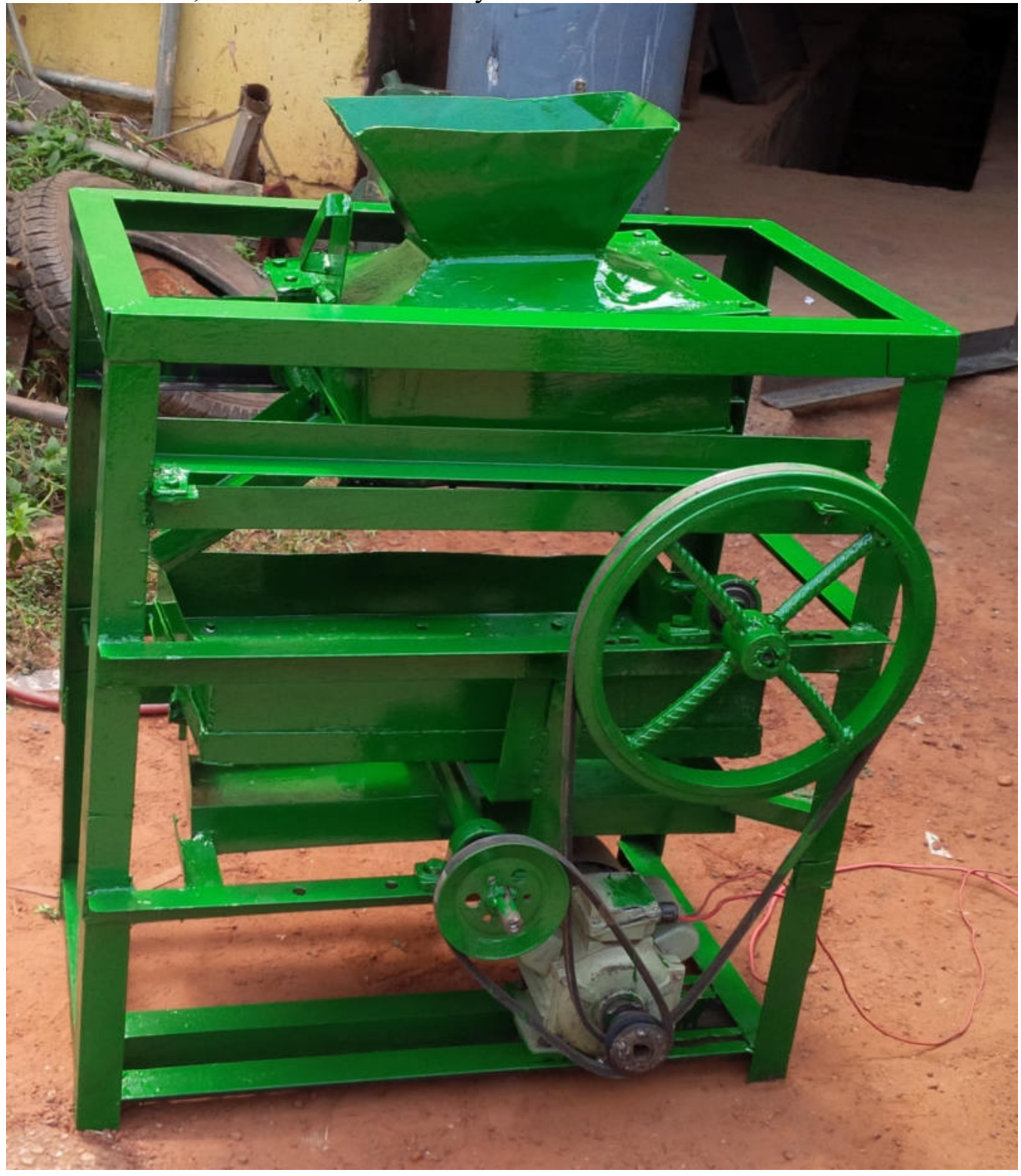

Plate 1: Fabricate Machine 


\section{Design Calculations of Component Parts}

Feed hopper

The cross sectional area and volume of the feed hopper was estimated to allow feeding of the admixture into the hopper for destoning.

The material used was a 20 gauge steel plate and the shape of the hopper is a frustum of a pyramid.

\section{Weight of Shafts}

$$
\begin{aligned}
& \begin{array}{r}
\text { Base area } A=l \times b \\
=30 \times 25.8=774 \mathrm{~cm}^{2}
\end{array} \\
& \text { Volume of hopper } V=\frac{1}{3} \times A \times h \\
& \text { Where, } \\
& \mathrm{A}=\text { base area } \\
& \mathrm{h}=\text { height. } \\
& \text { Volume of hopper } V=\frac{1}{3} \times 774 \times 20 \\
& =5,160 \mathrm{~cm}^{3}
\end{aligned}
$$

\section{i. Upper shaft (For First Sieve)}

Shaft material is mild steel with density of $7.83 \times 10^{3} \mathrm{~kg} / \mathrm{m}^{3}$

$$
\begin{aligned}
\text { Area } A & =\pi \mathrm{D}^{2} / 4 \\
\mathrm{D} & =25 \mathrm{~mm} \\
\mathrm{~A} & =490.94 \mathrm{~mm}^{2}
\end{aligned}
$$

Volume of shaft $\mathrm{V}=\mathrm{A} \times \mathrm{L}$

$\mathrm{L}=500 \mathrm{~mm}$

$\mathrm{A}=490.94 \mathrm{~mm}^{2}$

$\mathrm{V}=490.94 \times 500=2.45 \times 10^{-2} \mathrm{~m}^{3}$

$$
\text { Mass of shaft } m=\rho V
$$

Where, $\rho=$ density of shaft material $=7.83 \times 10^{3} \mathrm{~kg} / \mathrm{m}^{3}$

$\mathrm{V}=$ volume of shaft $=2.45 \times 10^{-4} \mathrm{~m}^{3}$

$\mathrm{m}=2.45 \times 10^{-2} \times 7.83 \times 10^{3}=192 \mathrm{~kg}$

Weight of shaft $\mathrm{W}=192 \times 9.81=1885.5 \mathrm{~N}$

\section{ii. Lower Shaft (Reciprocating Shaft)}

$$
\begin{aligned}
& \mathrm{A}=\pi \mathrm{D}^{2} / 4 \\
& \mathrm{D}=25 \mathrm{~mm} \\
& \mathrm{~A}=490.94 \mathrm{~mm}^{2}
\end{aligned}
$$

Volume of shaft $\mathrm{V}=\mathrm{A} \times \mathrm{L}$

$\mathrm{L}=400 \mathrm{~mm}$

$\mathrm{A}=490.94 \mathrm{~mm}^{2}$

$\mathrm{V}=490.94 \times 400=1.96 \times 10^{-2} \mathrm{~m}^{3}$

Mass $\mathrm{m}=\rho \mathrm{V}$

$=7.83 \times 10^{3} \times 1.47 \times 10^{-2}$

$=115.1 \mathrm{~kg}$

Weight $\mathrm{W}=115.1 \times 9.81$

$$
=1129.14 \mathrm{~N}
$$




\section{Determination of Pulley Dimension}

i. Upper Shaft Pulley: The expression to obtain the pulley dimension is given by Hannah (1984) as:

$$
\mathrm{N}_{1} \mathrm{D}_{1}=\mathrm{N}_{2} \mathrm{D}_{2}
$$

Where, $\mathrm{N}_{1}=$ Speed of Driving pulley (electric motor) $=1426 \mathrm{rpm}$

$\mathrm{D}_{1}=$ Diameter of driving Pulley $=50 \mathrm{~mm}$

$\mathrm{N}_{2}=$ speed of driven pulley $366 \mathrm{rpm}$

$\mathrm{D}_{2}=$ diameter of driven pulley

$\mathrm{D}_{2}=\mathrm{N}_{1} \mathrm{D}_{1} / \mathrm{N}_{2}=350 \mathrm{~mm}$

\section{ii. Reciprocating Shaft Pulley}

$\mathrm{N}_{2} \mathrm{D}_{2}=\mathrm{N}_{3} \mathrm{D}_{3}$

Where, $\mathrm{N}_{2}=$ speed of the upper pulley $(366 \mathrm{rpm})$

$\mathrm{D}_{2}=$ diameter of the lower pulley $(130 \mathrm{~mm})$

$\mathrm{N}_{3}=$ speed of reciprocating shaft $(160 \mathrm{rpm})$

$\mathrm{D}_{3}=$ diameter of reciprocating shaft.

Ogunlowo and Adesoyi (1999) found that reciprocating sieves performed effectively at crank speed of 160rpm.

$\mathrm{D}_{3}=\mathrm{N}_{2} \mathrm{D}_{2} / \mathrm{N}_{3}=228.8 \mathrm{~mm}$

A standard pulley of $220 \mathrm{~mm}$ diameter was selected

\section{Belt Selection}

Selection of belt was based on ASAE standard (1979) which gives the relationship,

$$
L=\frac{\pi}{2}\left(D_{1}+D_{2}\right)+2 x+\frac{\left(D_{1}+D_{2}\right)^{2}}{4 x} \mathrm{~g}
$$

Where, $\mathrm{L}=$ effective length of belt

$\mathrm{x}=$ Centre distance from driving to driven pulley

$\mathrm{D}_{1}=$ diameter of larger pulley

$\mathrm{D}_{2}=$ diameter of smaller pulley

$\mathrm{L}=2(620)+1.57(350-130)+(350-130)^{2} / 4(620)=1604 \mathrm{~mm}$

Standard belts of B55 size v- belt with the following dimensions selected;

Top width, $b_{t}=11 \mathrm{~mm}$

Bottom width, $b_{b}=6 \mathrm{~mm}$

Thickness, $\mathrm{t}=9 \mathrm{~mm}$

Cross sectional area of belt is given by, $\mathrm{A}=\left(\mathrm{b}_{\mathrm{t}}+\mathrm{b}_{\mathrm{b}}\right) \mathrm{t} / 2$ (Hannah, 1984) $\mathrm{A}=(11+6) 9 / 2=76.5 \mathrm{~mm}^{2}$

\section{Bearing Selection}

These were based on ASAE (1972) standard. Factors considered are;

i. $\quad$ Speed of shaft

ii. Size of shaft

A single row deep groove ball bearing 6308 was selected with inner diameter of $20 \mathrm{~mm}$ and external diameter of $40 \mathrm{~mm}$ for the reciprocating shaft. SKF explorer 6205 was selected with inner diameter of $25 \mathrm{~mm}$ and external diameter of $50 \mathrm{~mm}$ for the shaft. 


\section{Total Weight on Shaft}

Mass of pulley $=3.5 \mathrm{~kg}$,

weight of pulley $=3.5 \times 9.81=34.34 \mathrm{~N}$

\section{Bending Moment and Torsion Moment on shaft}

\section{i. Torsion Moment}

The torsion moment, $\mathrm{m}_{\mathrm{t}}$ acting on the shaft can be determine using,

$$
m_{t}=\frac{k w \times 100 \times 60}{2 \pi N}
$$

Where, $\mathrm{kW}=$ power in kilowatt

$$
\mathrm{N}=\text { speed of shaft in rpm. }
$$

The electric motor to be used is $2 \mathrm{hp}$

$$
\mathrm{N}=366 \mathrm{rpm}
$$

Therefore,

$$
m_{t}=2 \times 100 \times 60 / 2 \pi \times 366=5.22 \mathrm{Nm} .
$$

ii. Maximum Bending Moment, $\mathbf{m}_{\mathbf{b}}$

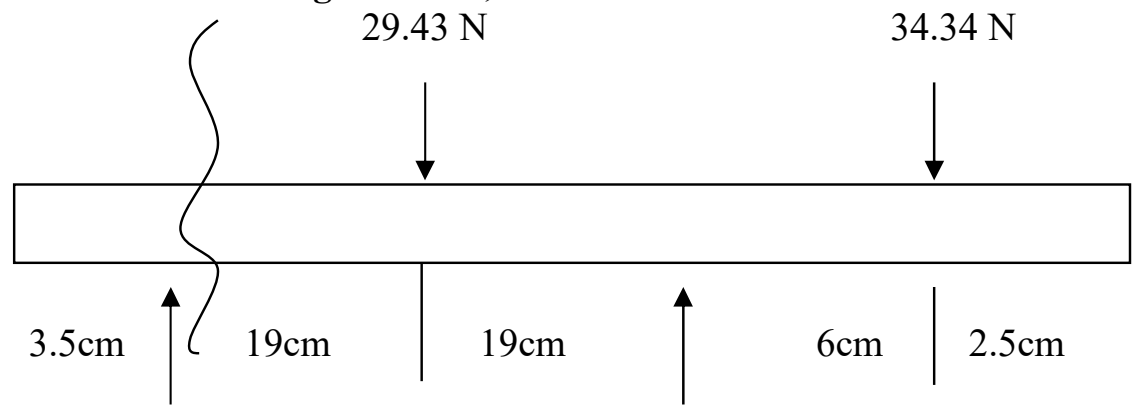

$$
\begin{aligned}
\mathrm{R}_{1}+\mathrm{R}_{2}=63.77 \mathrm{~N} \\
\quad \mathrm{R}_{2}=0 \\
\Rightarrow \quad \mathrm{R}_{1}(38)-29.43(19) . \\
\Rightarrow \quad \mathrm{R}_{1}=14.72 \mathrm{~N} \\
\Rightarrow \quad \mathrm{R}_{2}=49.06 \mathrm{~N} \\
\mathrm{M}_{\mathrm{x}}=34.34(\mathrm{x}-2.5)-49.06(\mathrm{x}-8.5)+29.43(\mathrm{x}-27.5)
\end{aligned}
$$

Boundary conditions:

$$
\begin{aligned}
& 0<\mathrm{x}<0.05 \\
& 0<\mathrm{x}<0.1 \\
& 0<\mathrm{x}<0.3
\end{aligned}
$$

At $\mathrm{x}=0.05$,

$$
\begin{aligned}
\mathrm{M}_{\mathrm{x}}=34.34(0.05-2.5)-49.06(0.05-8.5)+29.43(0.05-27.5) \\
\\
\mathrm{M}_{\mathrm{x}}=4.77 \mathrm{Nm} \\
\text { At } \mathrm{x}=0.1 \\
\mathrm{M}_{\mathrm{x}}=34.34(0.1-2.5)-49.06(0.1-8.5)+29.43(0.1-27.5) \\
\mathrm{M}_{\mathrm{x}}=4.76 \mathrm{Nm} \\
\text { At } \mathrm{x}=0.3 \\
\mathrm{M}_{\mathrm{x}}=34.34(0.3-2.5)-49.06(0.3-8.5)+29.43(0.3-27.5) \\
\mathrm{M}_{\mathrm{x}}=4.73 \mathrm{Nm}
\end{aligned}
$$

Therefore, Maximum bending moment $\mathrm{Mx}=4.77 \mathrm{Nm}$ 


\section{Shaft Diameter}

Where;

$$
d_{s}^{3}=\frac{16}{\prod S_{s}} \sqrt{\left(K_{b} M_{b}\right)^{2}+\left(K_{t} M_{t}\right)^{2}}
$$

$\mathrm{M}_{\mathrm{b}}=$ maximum bending moment;

$\mathrm{M}_{\mathrm{t}}=$ maximum twisting moment;

$\mathrm{K}_{\mathrm{b}}=$ combined shock and fatigue factor applied to bending moment;

$\mathrm{Kt}=$ combined shock and fatigue factor applied to twisting moment;

Ss $=$ Ultimate stress of mild steel $=55 \times 10^{6} \mathrm{~N} / \mathrm{m}^{2}$

$$
\mathrm{d}_{\mathrm{s}}^{3}=\frac{16}{\pi \times 55 \times 10^{6}} \sqrt{(1.5 \times 4.77)^{2}+(1 \times 5.22)^{2}}
$$

The nearest shaft size most suitable and available was selected with diameter of $25 \mathrm{~mm}$.

\subsubsection{Shear Force and Bending Moment Diagrams}

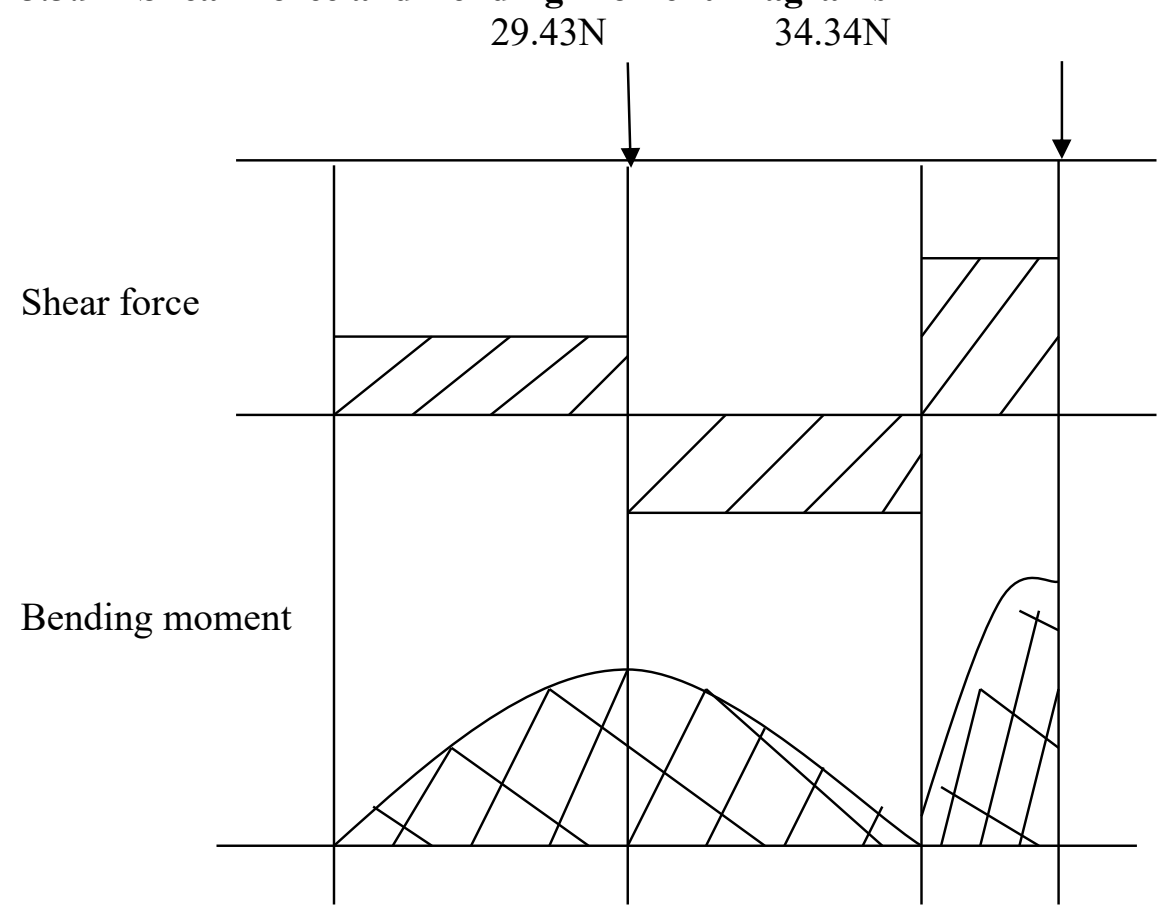

Fig. 1 Shear Force and Bending Moment Diagrams

\section{Experimental Procedure}

Clean rice grains were purchased from Uchi market, sand particles and stones are also weight separately and the masses recorded. Rice and stones are then mixed thoroughly and the admixture feed into the hopper as the electric motor was started. When destoning is finished, the clean rice was then weighed again and the mass recorded stones separated are also weighed separately and the masses recorded. Each experiment lasted for a minimum of 5-8 mins at an average speed of $366 \mathrm{rpm}$.

\subsection{Material Selection}

The particular conditions under which the various parts of the Rice de-stoning machine are subjected to, makes it necessary to select adequate materials for the fabrication based on functionality, durability, ability to withstand vibration and the cost of such materials as shown in Table 3.1. In the choice of material, their physical properties and behaviour are considered 
such that when subjected to the machine running condition should be able to withstand the service condition.

In this design, the strength of the materials, serviceability of parts and availability were put into consideration. This led to the selection of mild steel angle bar $(40 \times 40 \mathrm{~mm})$ for the frame, mild steel angle bar $(25 \times 25 \mathrm{~mm})$ for the working decks and gauge 24 mild steel sheets for the protective guards and hopper. For the pulley, aluminum was selected for light weight and mild steel plates selected for the exciter disc. Also, painting of the machine was carried out for aesthetic aspect and to prevent rusting of parts.

\subsection{RESULTS AND DISCUSSION}

Results

The results of the tests are shown in the tables below. From the results of admixture of rice and stones being separated by the machine and weighed separately.

Table 1: Quantity of Admixture fed into the hopper

\begin{tabular}{ccccccc}
\hline S/N & $\begin{array}{c}\text { Weight } \\
\text { of } \\
\text { clean } \\
\text { Rice (g) }\end{array}$ & $\begin{array}{c}\text { Weight of } \\
\text { stones (g) }\end{array}$ & $\begin{array}{c}\text { Total Weight } \\
\text { of Admixture } \\
\text { (g) }\end{array}$ & $\begin{array}{c}\text { Weight of } \\
\text { Rice } \\
\text { Collected (g) }\end{array}$ & $\begin{array}{c}\text { Weight of } \\
\text { stones } \\
\text { collected (g) }\end{array}$ & $\begin{array}{c}\text { Losses } \\
\text { (g) }\end{array}$ \\
\hline 1 & $1,000.00$ & 100 & $1,100.00$ & 860.00 & 90.00 & 150 \\
2 & $1,000.00$ & 200 & $1,200.00$ & 831.00 & 188.00 & 181 \\
3 & $1,000.00$ & 300 & $1,300.00$ & 822.00 & 270.00 & 208 \\
4 & $1,000.00$ & 400 & $1,400.00$ & 865.00 & 377.00 & 158 \\
5 & $1,000.00$ & 500 & $1,500.00$ & 790.00 & 463.00 & 247 \\
6 & $1,000.00$ & 600 & $1,600.00$ & 737.00 & 571.00 & 292 \\
\hline
\end{tabular}

From table 4.1, the parameter were used to calculate the Rice separation efficiency (RSE), stone separation efficiency (SSE), Impurity level after separation (IMLAS) and the Tray Losses $\left(T_{L}\right)$ as shown in Table 4.2. It was on this basis conclusion was drawn about the performance of the machine.

Table 2: Results Performance Evaluation

\begin{tabular}{ccccc}
\hline S/N & $\begin{array}{c}\text { Impurity level after } \\
\text { separation (\%) }\end{array}$ & $\begin{array}{c}\text { Rice Separation } \\
\text { Efficiency } \mathbf{( \% )}\end{array}$ & $\begin{array}{c}\text { Stone Separation } \\
\text { Efficiency } \mathbf{( \% )}\end{array}$ & $\begin{array}{c}\text { Tray } \\
\text { Loss } \mathbf{( \% )}\end{array}$ \\
\hline 1 & 9.47 & 86.0 & 10.00 & 14.00 \\
2 & 18.45 & 83.1 & 6.00 & 16.90 \\
3 & 24.73 & 82.2 & 10.00 & 17.80 \\
4 & 30.35 & 86.5 & 5.75 & 13.50 \\
5 & 36.95 & 79.0 & 7.40 & 21.00 \\
6 & 43.65 & 73.7 & 4.83 & 26.30 \\
\hline Mean & 27.27 & 81.75 & 7.33 & 18.25 \\
\hline
\end{tabular}

\section{Discussion of Result}

The result of the test carried out to evaluate the performance of the destoner is given in Table 4.2. The result showed an average of $81.75 \%, 7.33 \%, 18.25 \%$ and $27.27 \%$ for rice separation efficiency, stone separation efficiency, Tray loss and impurity after separation respectively for the rice variety. Also shown in figure 4.1 are the graphical relationship between the performance parameters and the feed rate of the admixtures. 


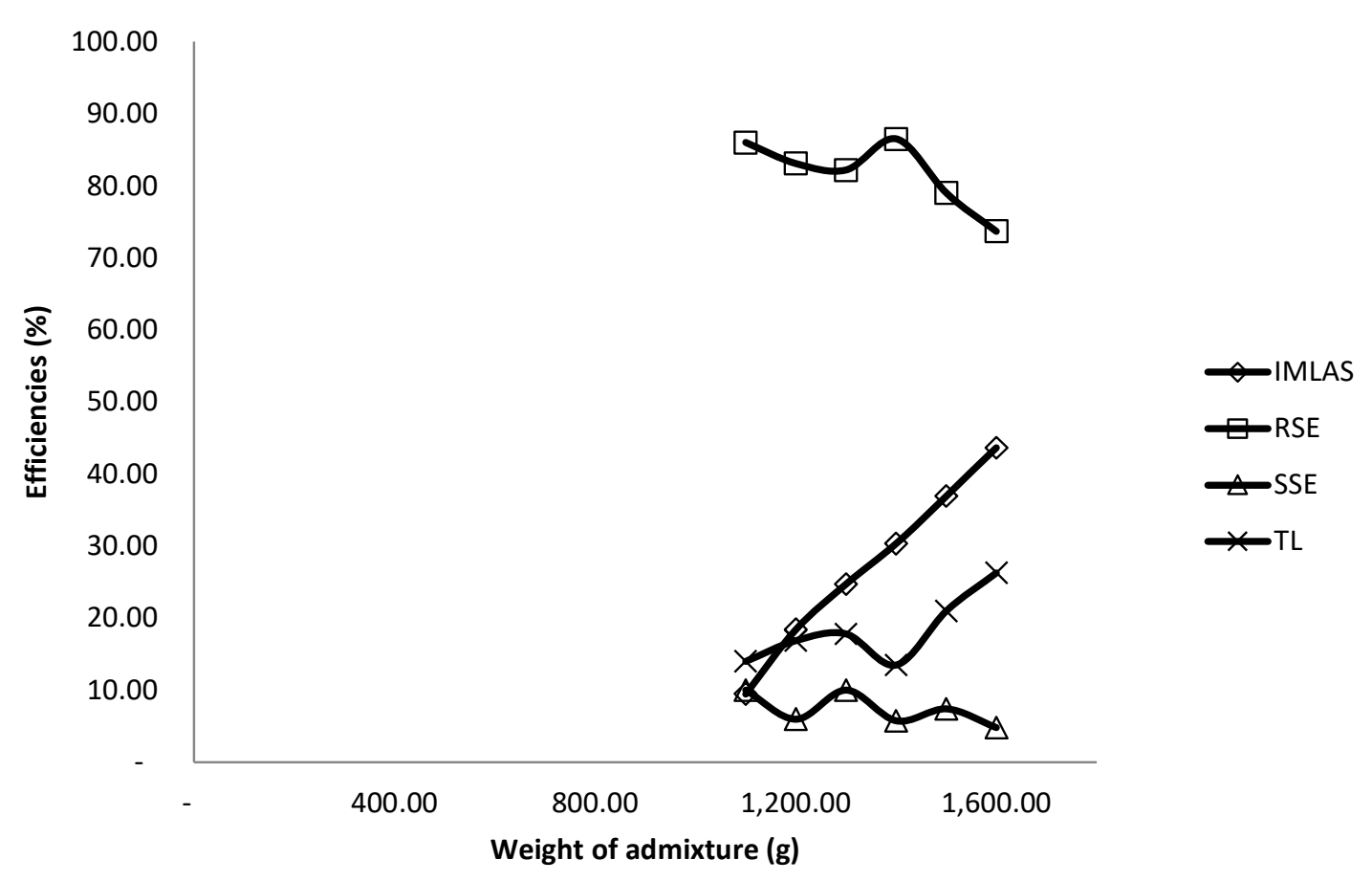

Figure 2: Efficiency - Feed rate relations

The rice separation efficiency obtained was lower than $82.18 \%$ rice separation efficiency obtained by Ogunlowo and Adesuyi, (1999). The tray loss and impurity level after separation were however higher than $17.82 \%$ and $9.43 \%$ obtained by Ogunlowo and Adesuyi, (1999). This result is in close agreement with that obtained by Okopi (2002) who designed and fabricated a Rice Destoning Machine with an efficiency of $82.47 \%$ attained. The machine was tested and found capable of de-stoning rice. Due to the low cost of fabrication the machine can be adopted by small scale producers.

\section{CONCLUSION}

A rice destoning machine operating on mechanical principles of reciprocating and vibrating sieves was fabricated. The machine was tested in terms of the rice separation efficiency, stone separation efficiency, tray loss and impurity level after separation.

The result showed an average of $81.75 \%, 7.33 \%, 18.25 \%$ and $27.27 \%$ for rice separation efficiency, stone separation efficiency, tray loss and impurity after separation respectively for local rice variety under study. The developed machine has the promise of solving the problem of stone infestation usually encountered in locally produced rice.

The machine has the potential of being adopted for destoning other rice varieties and grading rice (separating full grains from broken grains).

\section{REFERENCES}

ASAE (1979). Evaluation of a simulation model of combine harvester. Proceedings of the international grain and forage harvesting conference Michigan, U.S.A.

FAO (2000). Food balance sheet table 1.1 - Nigeria, Rome.

Global Agriculture Information Network (GAIN) (2005): "Nigeria Grain and Feed Annual 2005”. GAIN Report Number: NI5005.. U.S. Consulate, Lagos

Hannah, J. and Stephen, R.C (1984). Mechanics of Machines. $3^{\text {rd }}$ Edition. Edward Arnol 
(Publishers) Ltd, London

Henderson, S. M, and R. L. Perry. (1976). Agriculture process engineering. $3^{\text {rd }}$ edition. The AVI Publishing Company incorporated. Westport Connecticut page 108-109.

Ndirika, V. I. O. (1993). Development and Performance Evaluation of a Millet Thresher. Journal of Agricultural Technology pp 1-8

Ogunlowo, A. S, (1999). A low Cost Rice Cleaning/Destoning Machine. A. M. A. 30(1).

Okopi, A.G (2002). Design, Fabrication and perfomance evaluation of rice destoner. Project report, Agricultural Engineering Department. Ahmadu Bello University Zaria.

Oni, C.A and Olayemi, J.K (1973):"Economics of Rice Milling in Kwara and NorthWestern. Available at www.mechricenaija.com

Tukuru, T. B. (2000). Design, Development and perfomance evaluation of manually operated grain cleaner. Project report, Agricultural Engineering Department. Ahmadu Bello University Zaria.

Wudiri, B.B and Fatoba, I.O (1992): Cereals in the Food Economy of Nigeria". In Lawani, S.M and Babaleye, T (Eds): Proceedings of the Workshop on Recent Developments in Cereal Production in Nigeria Held at Durbar Hotel. Kaduna State (1992). 